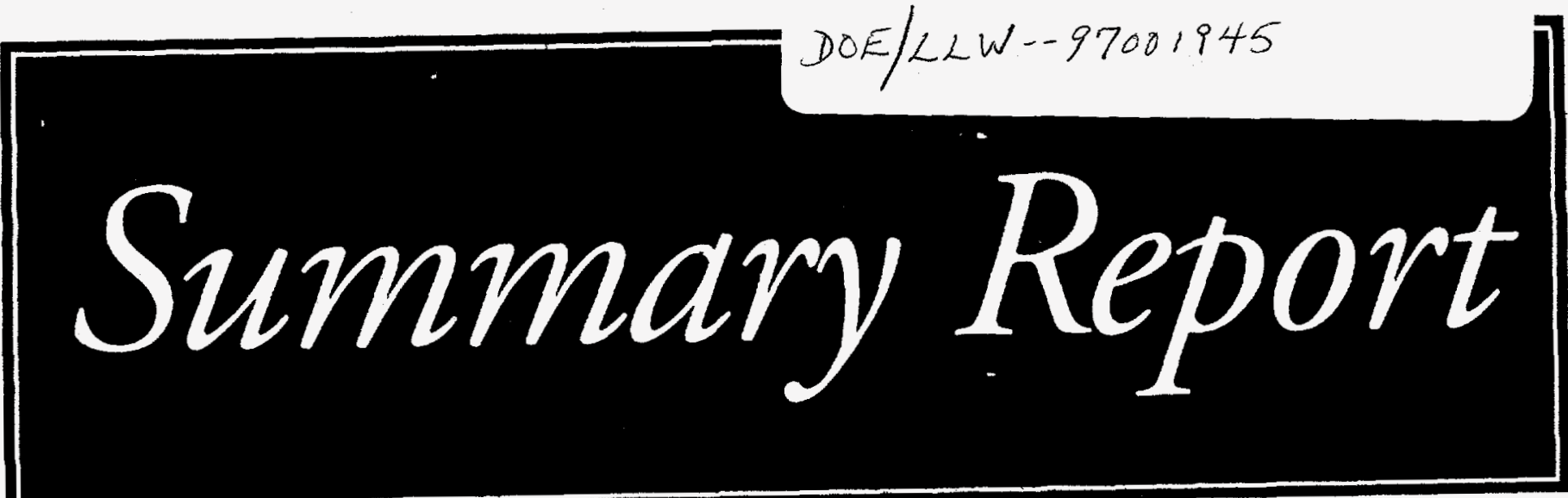

Volume 4, Number I January 1996

\title{
Low-Level
}

\section{Radioactive Waste}

Management

Activities

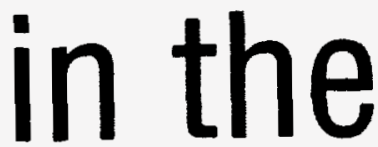

States

and

\section{DISCLAIMER}

This report was prepared as an account of work sponsored by an agency of the United States Government. Neither the United States Government nor any agency thereof, nor any of their employees, makes any warranty, express or implied, or assumes any legal liability or responsibility for the accuracy, completeness, or usefulness of any information, apparatus, product, or process disclosed, or represents that its use would not infringe privately owned rights. Reference herein to any specific commercial product, process, or service by trade name, trademark, manufacturer, or otherwise does not necessarily constitute or imply its endorsement, recommendation, or favoring by the United States Government or any agency thereof. The views and opinions of authors expressed herein do not necessarily state or reflect those of the United States Government or any agency thereof.

\section{Compacts}




\section{Summary Report: Low-Level Radioactive Waste Management Activities in the States and Compacts A supplement to LLW Notes \\ Volume 4, Number 1 - January 1996 \\ Editor, Cynthia Norris \\ Contributing Writers: LLW Forum Participants and Alternate Forum Participants \\ Project Manager: Jean Colsant \\ Layout and Design: M. A. Shaker}

Summary Report: Low-Level Radioactive Waste Management Activities in the States and Compacts is a supplement to $L L W$ Notes and is distributed periodically by Afton Associates, Inc. to state, compact and federal officials that receive $L L W$ Notes.

Members of the public may apply to DOE's National LowLevel Waste Management Program at the Idaho National Engineering Laboratory (INEL) to be placed on a public information mailing list for copies of the Summary Report. Interested parties should contact Donna Lake, Senior Administrative Specialist, INEL, at (208)526-0234.

Recipients may reproduce and distribute the Summary Report as they see fit, but sections in the Summary Report must be reproduced in entirety and with full attribution. Forum Participants may contact Cynthia Norris to request camera-ready copy of this edition of the Summary Report.

The Low-Level Radioactive Waste Forum (LLW Forum) is an association of state and compact representatives, appointed by governors and compact commissions, established to facilitate state and compact implementation of the Low-Level Radioactive Waste Policy Act of 1980 and the Low-Level Radioactive Waste Policy Amendments Act of 1985 and to promote the objectives of low-level radioactive waste regional compacts. The LLW Forum provides an opportunity for state and compact officials to share information with one another and to exchange views with officials of federal agencies and other interested parties.

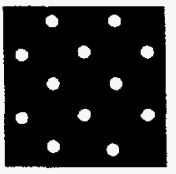

Low-Level Radioactive Waste Forum c/o Afton Associates, Inc. 403 East Capitol Street Washington, DC 20003

\section{LLW} voice (202)547-2620 FORUM fax (202) 547-1668

internet llwforum@aol.com

\section{Key to Abbreviations}

U.S. Department of Energy

DOE

naturally-occurring and accelerator-produced radioactive materials

naturally-occurring radioactive materials

U.S. Nuclear Regulatory Commission
NARM

NORM

NRC 


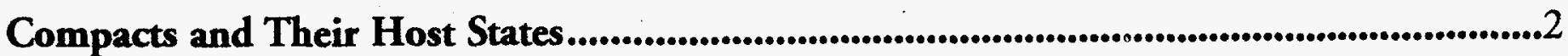

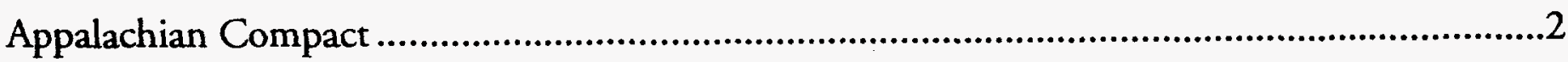

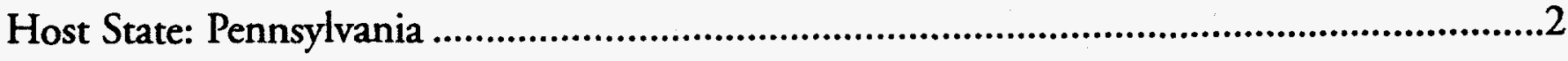

Central Compact...........................................................................................................

Host State: Nebraska ...................................................................................................

Central Midwest Compact .................................................................................................4

Host State: Illinois ............................................................................................................4

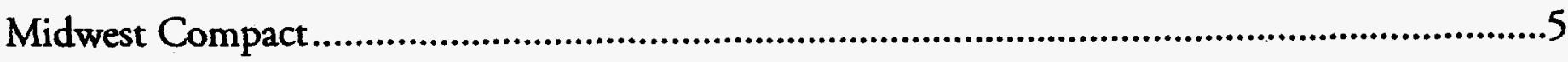

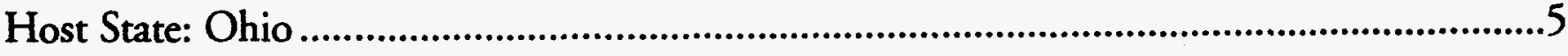

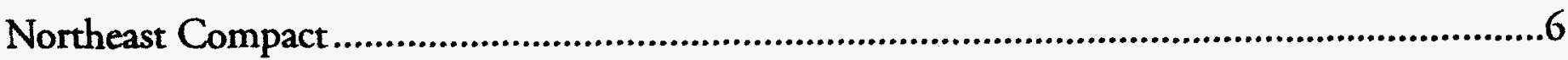

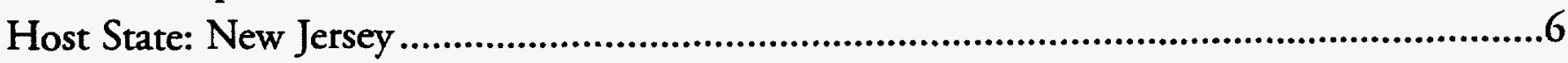

Host State: Connecticut ............................................................................................

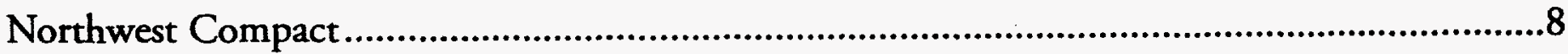

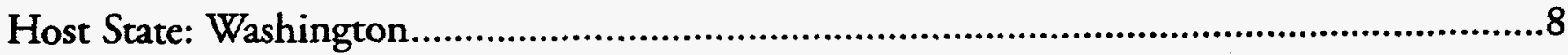

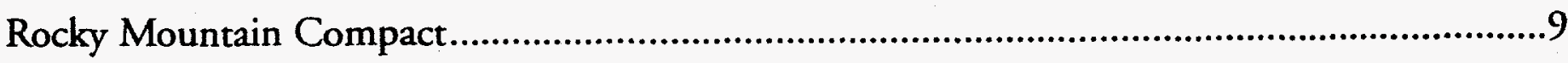

Southeast Compact ............................................................................................................10

Host State: North Carolina ................................................................................................10

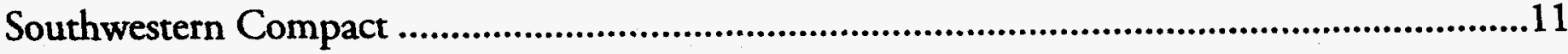

Host State: California...................................................................................................11

Texas Compact (pending).................................................................................................12

Host State: Texas ......................................................................................................13

Unaffiliated States .....................................................................................................................14

Massachusetts........................................................................................................14

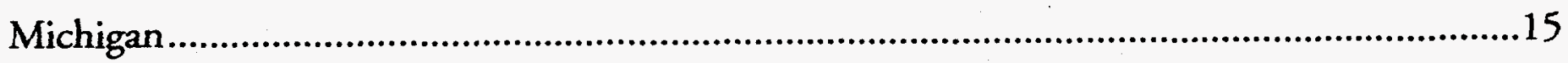

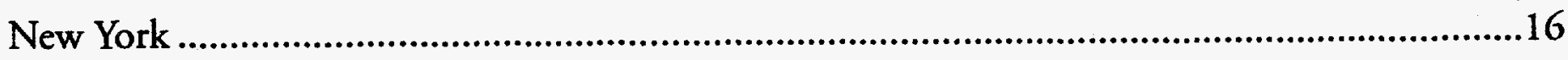

South Carolina .........................................................................................................17

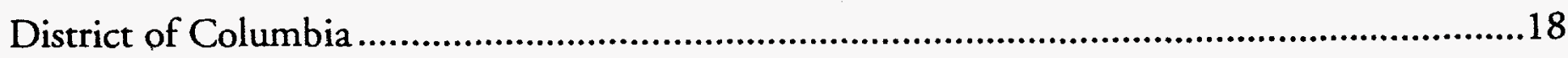

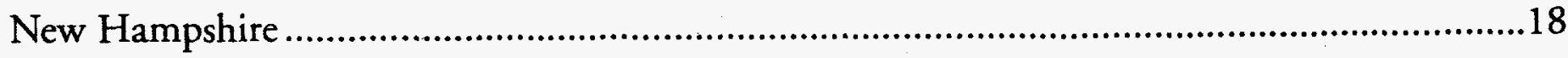

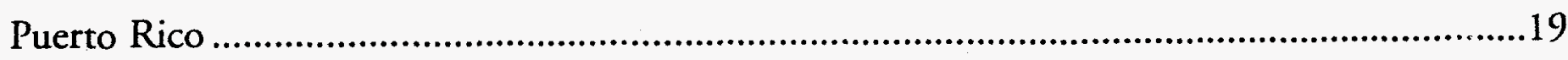

Rhode Island ..............................................................................................................19 


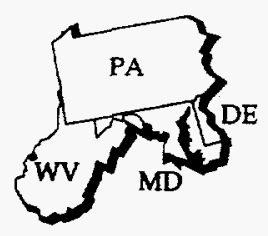

\title{
Appalachian Compact
}

Governing Body Appalachian States Low-Level Radioactive Waste Commission

Member States Delaware, Maryland, Pennsylvania, West Virginia

Compact Established The compact was established February 19, 1986, and ratified by Congress on May 19, 1988. The commission's first organizational meeting was held April $30,1990$.

Jurrent Waste Management As of July 1, 1995, waste may be shipped to the disposal facility in Barnwell, South Carolina. In addition, subject to the Northwest Compact rules of April 20, 1995, wastes meeting Envirocare of Jtah's license conditions are being shipped for disposal at the Envirocare facility. Certain NARM wastes meeting he State of Washington's conditions are being shipped to the commercial disposal facility in Hanford, Washington.

\section{Host State: Pennsylvania}

\author{
Regulatory and Program \\ iesponsibility \\ Bureau of Radiation Protection, \\ Department of Environmental Protection (DEP) \\ iting Responsibility \\ Chem-Nuclear Systems, Inc. \\ ther Involvement \\ DEP Low-Level Waste Advisory Committee \\ Environmental Quality. Board \\ Disposal Technology \\ earth-mounded above-ground vault
}

iting Pennsylvania has completed the final stage of a three-stage disqualification process. About 75 percent of 'ennsylvania has been disqualified from further consideration. Pennsylvania is developing a volunteer community iting program which is expected to be approved in January 1996. The search for a volunteer community is xpected to take about three years.

icensing Chem-Nuclear will submit a license application to DEP. Pennsylvania has applied for limited greement State status with NRC. A time frame for licensing has not yet been established for the new volunteer ommunity siting program.

Development Costs To date: $\$ 35$ million. Estimated total cost including construction: not provided.

Jisposal Facility Operational A projected completion date is not available. 


\section{DISCLAIMER}

Portions of this document may be illegible in electronic image products. Images are produced from the best available original document. 


\section{Compactś and Their Host States (continued)}

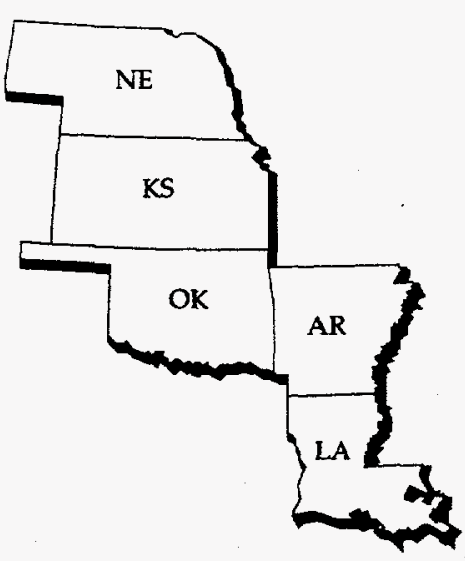

\section{Central Compact}

Governing Body Central Interstate Low-Level Radioactive Waste Commission

Member States Arkansas, Kansas, Louisiana, Nebraska, Oklahoma

Compact Established The compact was established May 12, 1983. The commission's organizational meeting was held June 29, 1983.

Current Waste Management As of July 1, 1995, waste may be shipped to the disposal facility in Barnwell, South Carolina. In addition, subject to the Northwest Compact rules of April 20, 1995, wastes meeting Envirocare of Utah's license conditions are being shipped for disposal at the Envirocare facility. Certain NARM wastes meeting the State of Washington's conditions can be shipped to the commercial disposal facility in Hanford, Washington.

Development Costs As of October 31,1995: \$73.4 million. Projected total cost including construction: $\$ 151.5$ million.

Disposal Facility Operational The Butte facility is projected to be operational no later than autumn 1999.

Other Information The Central States Compact Commission has begun the process to amend its Compact Act. The commission has approved draft amendmgnt language for review by member states.

\section{Host State: Nebraska}

\section{Regulatory and Program Department of Environmental Quality Responsibility Department of Health}

\section{Siting Responsibility US Ecology, Inc.}

Disposal Technology above-ground yault

Siting Property near Butte in Boyd County, Nebraska, was selected in December 1989.

Licensing A license application was submitted in July 1990. On May 31, 1995, US Ecology submitted to the host state its responses to their fourth and final round of technical comments on the application. On June 15, 1995, US Ecology submitted to the host state the eighth and final revision of the Safety Analysis Report (SAR) plus various other documents relating to the license application. The host state will continue its review of the license application. 


\section{Compacts and Their Host States (continued)}

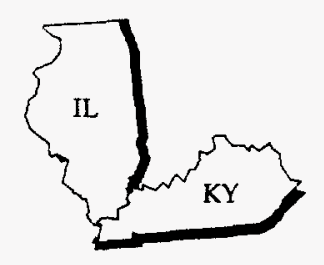

\section{Central Midwest Compact}

Governing Body Central Midwest Interstate Low-Level Radioactive Waste Commission

Member States Illinois, Kentucky

Compact Established The compact was established in September 1984, ratified by Congress effective January 986, and most recently amended and ratified in October 1994.

Current Waste Management As of July 1, 1995, waste may be shipped to the disposal facility in Barnwell, South arolina. In addition, subject to the Northwest Compact rules of April 20,1995, wastes meeting Envirocare of Jtah's license conditions are being shipped for disposal at the Envirocare facility. Certain NARM wastes meeting he State of Washington's conditions are being shipped to the commercial disposal facility in Hanford, Vashington.

\section{Host State: Illinois}

legulatory Responsibility Illinois Department of Nuclear Safery

rogram and iting Responsibility

Jisposal Technology
Low-Level Radioactive Waste Task Group-develop siting criteria

Illinois State Geological Survey and State Water Survey-statewide screening including evaluation of volunteer locations and identification of ten or more locations likely to meet the criteria

facility developer-evaluation of the locations, selection and characterization of site, preparation of license application, and facility development

Illinois Department of Nuclear Safety-licensing agency

iting The task group will develop siting criteria, and the Illinois Geological and Water Surveys will be responsible sr screening the state and evaluating any volunteered sites in order to locate at least 10 areas of at least 640 acres ach that appear likely to meet the criteria. The contractor will evaluate the areas identified by the Geological and Vater Surveys, select three promising sites for further study, and present findings to the task group. Following the isk group's approval of three sites, the contractor will select one final site for full characterization.

icensing A license application is expected to be submitted by November 1999.

Jevelopment Costs To date: information not provided. Estimated total cost including construction: information ot provided.

)isposal Facility Operational Projected by September 2003. 


\section{Compacts and Their Host States (continued)}

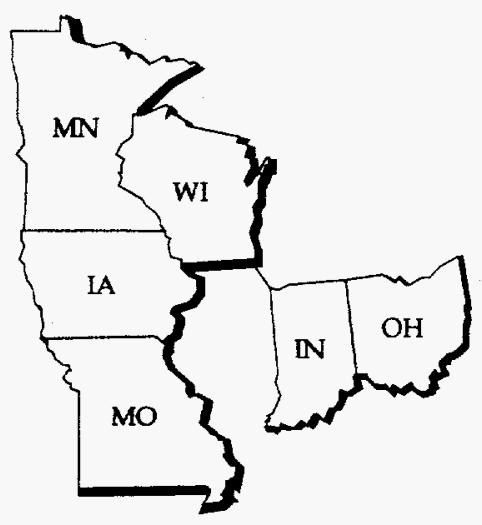

\section{Midwest Compact}

Governing Body Midwest Interstate Low-Level Radioactive Waste Compact Commission

Member States Indiana, Iowa, Minnesota, Missouri, Ohio, Wisconsin

Compact Established The compact was established in October 1983 and was given the consent of Congress in December 1985. Compact amendments were enacted by Ohio and Wisconsin in 1995. The amendments will be introduced in the state legislatures of Indiana, Iowa, MInnesota, and Missouri in January 1996.

Current Waste Management As of July 1, 1995, waste may be shipped to the disposal facility in Barnwell, South Carolina. In addition, subject to the Northwest Compact rules of April 20, 1995, wastes meeting Envirocare of Utah's license conditions are being shipped for disposal at the Envirocare facility. Certain NARM wastes meeting the State of Washington's conditions are being shipped to the commercial disposal facility in Hanford, Washington.

\section{Host State: Ohio}

Regulatory Responsibility Ohio Department of Health

Program Responsibility Ohio Low-Level Radioactive Waste Facility Development Authority (Authority)

Siting Responsibility Ohio Low-Level Radioactive Waste Facility Development Authority

Other Involvement

Radiation Advisory Council, state agencies

Disposal Technology

above-grade, multiple-barrier facility with continuous monitoring and waste recoverability

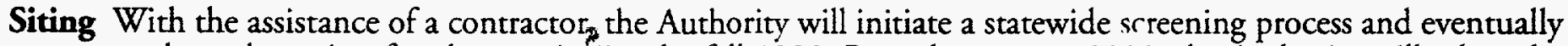
approve at least three sites for characterization by fall 1998. By early summer 2000 , the Authority will select the disposal site to be submitted for licensing.

Licensing Upon receipt of a license application, the Health Department will review the application and make a determination on compliance with all regulatory requirements. If requested by an affected party, a License Review Board will conduct an adjudicatory hearing following the department's determination. The Director of the department will issue a decision on the license application.

Development Costs To date: $\$ 664,300$ Also, $\$ 589,201$ expended on public information program. Estimated total cost including construction: not avallable.

Disposal Facility Operational Mid-2005. 


\section{Northeast Compact}

Governing Body Northeast Interstate Low-Level Radioactive Waste Commission

Member States Connecticut, New Jersey

Compact Established Congress ratified the compact in 1985, and it was signed into law by the President in 1986. Shortly thereafter, two of the four original member states-Delaware and Maryland-joined the Appalachian Compact. In 1987, the remaining member states of Connecticut and New Jersey were designated as dual host states.

Current Waste Management As of July 1, 1995, waste may be shipped to the disposal facility in Barnwell, South Carolina. In addition, subject to the Northwest Compact rules of April 20,1995, wastes meeting Envirocare of Utah's license conditions may be shipped for disposal at the Envirocare facility. Certain NARM wastes meeting the State of Washington's conditions may be shipped to the commercial disposal facility in Hanford, Washington.

\section{Host State: New Jersey}

Regulatory Responsibility NRC (New Jersey is not an Agreement State.)

New Jersey Department of Environmental Protection

Program Responsibility

New Jersey Low-Level Radioactive Waste Disposal Facility Siting Board (Siting Board)

Siting Responsibility

New Jersey Low-Level Radioactive Waste Disposal Facility Siting Board

Other Involvement

Disposal Technology
New Jersey Radioactive Waste Advisory Committee (RWAC)

State law precludes shallow land burial. The technology will depend on input from the volunteer community, site-specific requirements, and the ability of the technology to be licensed.

Siting The state's siting plan seeks a volunteer community to host a disposal facility and offers significant incentives.

Licensing New Jersey's current projected date of license submittal to NRC is 1999.

Development Costs To date: $\$ 3$ million. Estimated total cost including construction: $\$ 100$ million.

Disposal Facility Operational Projected by 2001.

Other Information In February 1995. the Siting Board approved a voluntary siting plan. Siting efforts are funded through generator assessments. 


\section{‘Compacts and Their Host States (continued)}

\section{Host State: Connecticut}

Regulatory Responsibility NRC (Connecticut is not an Agreement State.)

Connecticut Department of Environmental Protection

Program Responsibility Connecticut Office of Policy and Management-coordination

Connecticut Hazardous Waste Management Service-program

Siting Responsibility Connecticut Hazardous Waste Management Service

Other Involvement Connecticut Siting Council

Connecticut Department of Public Works

Disposal Technology

The Board of Directors of the Connecticut Hazardous Waste Management Service will select the technology in consultation with the volunteer community. The board has decided not to consider shallow land burial.

Siting The state's siting plan seeks a volunteer community to host a disposal facility and offers significant incentives. The state is prepared to use a statewide screening process if the volunteer approach does not produce a site that protects public health and safety.

Licensing Connecticut's current projected date of license submittal to NRC is 1999.

Development Costs To date: $\$ 9.4$ million. Estimated total cost including construction: $\$ 100$ million.

Disposal Facility Operational Projected by 2002.

Other Information Effective April 2, 1993, the Connecticut General Assembly approved the 1993 Low-Level Radioactive Waste Management Plan. The plan's volunteer siting approach is being implemented. Siting efforts are funded through generator assessments. 


\section{Northwest Compact}

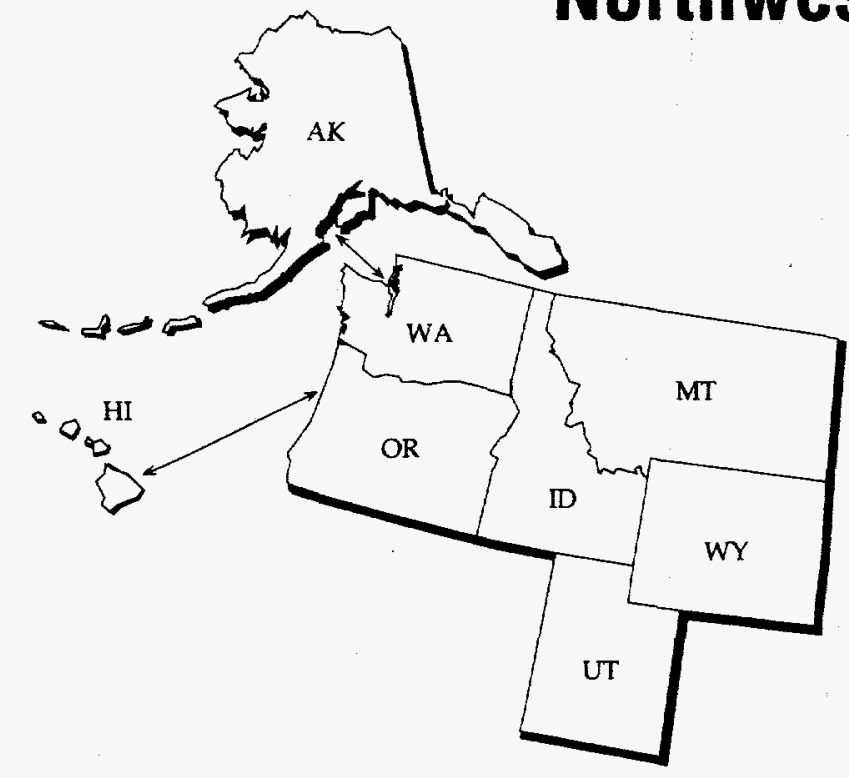

Governing Body Northwest Interstate Compact Committee

Member States Alaska, Hawaii, Idaho, Montana, Oregon, Utah, Washington, Wyoming

Compact Established The compact was established in 1981 and ratified by Congress in December 1985.

Current Waste Management Waste is disposed of at the regional commercial disposal facility in Hanford, Washington. In addition, subject to the Northwest Compact rules of April 20, 1995, wastes meeting Envirocare of Utah's license conditions are being shipped for disposal at the Envirocare facility. Certain NARM wastes meeting the State of Washington's conditions are being shipped to the Hanford facility.

\section{Host State: Washington}

Regulatory Responsibility Department of Health

Program Responsibility Department of Ecology

Disposal Technology shallow land burial

iiting The regional low-level radioactive waste disposal facility is located on the U.S. DOE Hanford reservation on 100 acres of land subleased by US Ecology from the State of Washington.

icensing The site operator's current materials license was issued by the Washington State Department of Health n May 29, 1992. The license next comes up for renewal on May 31, 1997.

Pevelopment Costs Not applicable.

Disposal Facility Operational The compact's regional disposal facility has been in operation since July 1965.

Dther Information The compact's low-level radioactive waste disposal site is not permitted for mixed waste. The fompact is working with other states and compacts to encourage DOE to provide for management of the ompact's mixed waste. 


\section{Compacts and Their Host States (continued)}

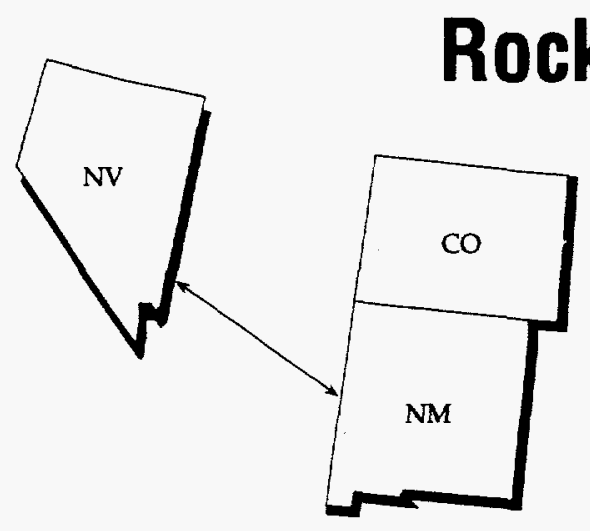

Governing Body Rocky Mountain Low-Level Radioactive Waste Board

Member States Colorado, Nevada, New Mexico

Compact Established The compact was established in 1983 and ratified by Congress in December 1985.

Current Waste Management The Rocky Mountain Board has a contract with the Northwest Interstate Compact Committee and the State of Washington for disposal at the Northwest Compact's regional commercial disposal facility in Hanford, Washington. In addition, subject to the Northwest Compact rules of April 20, 1995, wastes meeting Envirocare of Utah's license conditions are being shipped for disposal at the Envirocare facility. Certain NARM wastes meeting the State of Washington's conditions are being shipped to the Hanford facility.

Other Information Export authorization is required for all waste generated within the compact region that is sent outside of the region. Import authorization is required to bring out-of-compact waste into the region for management. No facilities within the compact region are currently authorized to receive out-of-compact waste. The compact has jurisdiction (including import and export authority) over NORM/NARM.

\section{Hóst State: None}




\section{Compacts and Their Host States (continued)}

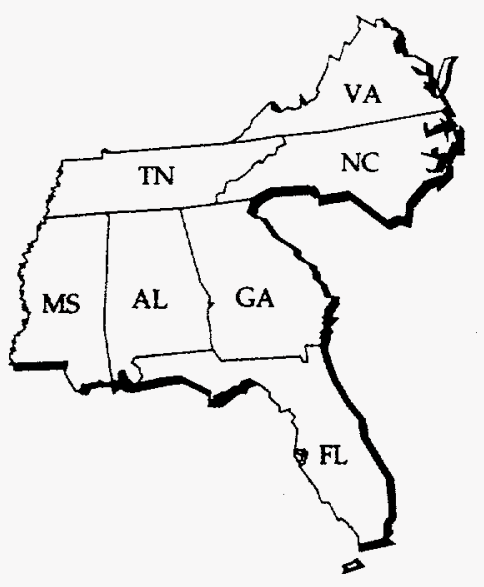

\section{Southeast Compact}

Governing Body Southeast Compact Commission for Low-Level

Radioactive Waste Management

Member States Alabama, Florida, Georgia, Mississippi, North Carolina, Tennessee, and Virginia

Compact Established The Southeast Compact was established in 1983 and ratified by Congress in 1985. The compact law was amended in 1989.

Current Waste Management As of July 1, 1995, waste from all member states except North Carolina may be shipped to the disposal facility in Barnwell, South Carolina. In addition, subject to the Northwest Compact rules of April 20, 1995, wastes meeting Envirocare of Utah's license conditions are being shipped for disposal at the Envirocare facility. Certain IARM wastes meeting the State of Washington's conditions are being shipped to the commercial disposal facility 2 Hanford, Washington.

ince July 1995, waste in North Carolina is being stored at the sites of generation.

\section{Host State: North Carolina}

egulatory Responsibility Division of Radiation Protection (DRP), North Carolina Department of Environment, Health and Natural Resources

rogram and

iting Responsibility

ther Involvement

pisposal Technology
North Carolina Low-Level Radioactive Waste Management Authority (Authority)

Chem-Nuclear Systems, Inc.-future facility operation

integrated vault

iting In December 1993, the Authority selected a site in Wake County as its preferred site.

icensing A license application was submitted by Chem-Nuclear to DRP in December 1993. It is expected that RP will not issue the license before 1998.

Pevelopment Costs To date: $\$ 90$ million. Estimated total cost excluding construction: $\$ 112.5$ million. Estimated ptal cost including construction: $\$ 180$ million.

Pisposal Facility Operational Projected by 1999.

Pther Information The Governor of North Carolina has stated that the ban on North Carolina waste at the arnwell facility is unconstitutional and may be challenged in court. 


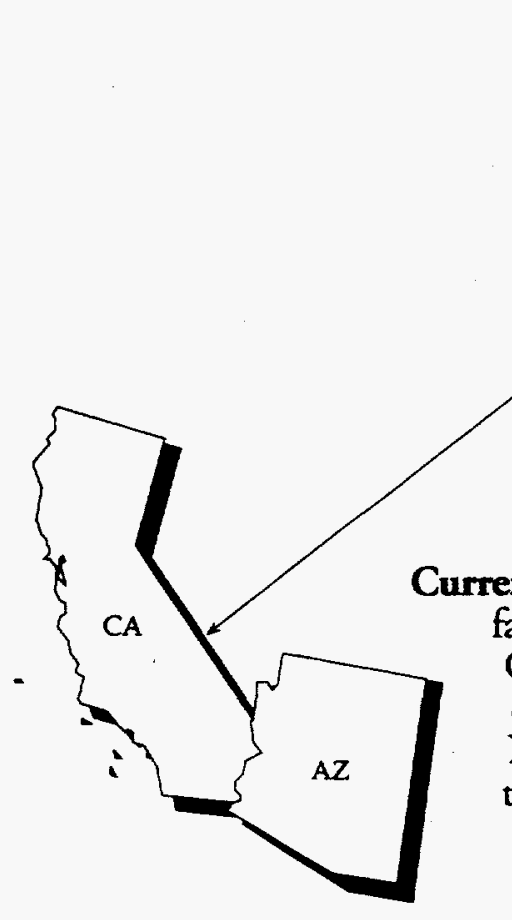

\section{Southwestern Compact}

Governing Body Southwestern Low-Level Radioactive Waste Commission

Member States Arizona, California, North Dakota, South Dakota

Compact Established The compact was established in July 1988 and ratified by Congress in November 1988. North Dakota and South Dakota joined the compact in 1989.

Current Waste Management As of July 1, 1995, waste may be shipped to the disposal facility in Barnwell, South Carolina. In addition, subject to the Northwest Compact rules of April 20, 1995, wastes meeting Envirocare of Utah's license conditions are being shipped for disposal at the Envirocare facility. Certain NARM wastes meeting the State of Washington's conditions are being shipped to the commercial disposal facility in Hanford, Washington.

\section{Host State: California}

Regulatory and Program

Responsibility

Siting Responsibility

Other Involvement

Disposal Technology
Department of Health Services (DHS)

US Ecology, Inc.

U.S. Bureau of Land Management (BLM)

enhanced shallow land burial

Siting The property in Ward Valley designated as the preferred site by US Ecology in 1988 is currently owned by the federal government. California is working with BLM to transfer the land to the state.

Licensing A license was issued by DHS on September 16,1993, conditioned on DHS ownership of the land. On June 1, 1994, the Superior Court of the State of California ordered DHS to "reconsider its approval of the license." The Court of Appeal of the State of California, Second District, overturned the lower court decision and reinstated the license. On January 18, 1996, the Supreme Court of California denied the plaintiff's petition to review the appellate court's decision. There are no further avenues for appeal available in the state court system.

Development Costs As of November 1, 1995: \$62.6 million (estimated \$64.1 million ty December 31). Estimated total cost including construction: $\$ 97$ million.

Disposal Facility Operational Projected by mid-1997 contingent upon the outcome of legal actions.

Other Information At the request of the U.S. Interior Secretary, a National Academy of Sciences committee reviewed seven technical issues related to the site and found no obstacles to proceeding with development. Based on this analysis the Department of the Interior has indicated willingness to transfer land for the facility to the state, subject to certain "enforceable commitments." The state, the developer and the generators object to this intrusion into a matter under the state's jurisdiction. The U.S. Congress is seeking to legislatively transfer the land.

The license issued by DHS does not include mixed waste disposal. The Southwestern Commission and DHS are working with other states and compacts to encourage DOE to provide for management of commercial mixed waste. 


\section{Compacts and Their Host States (continued)}

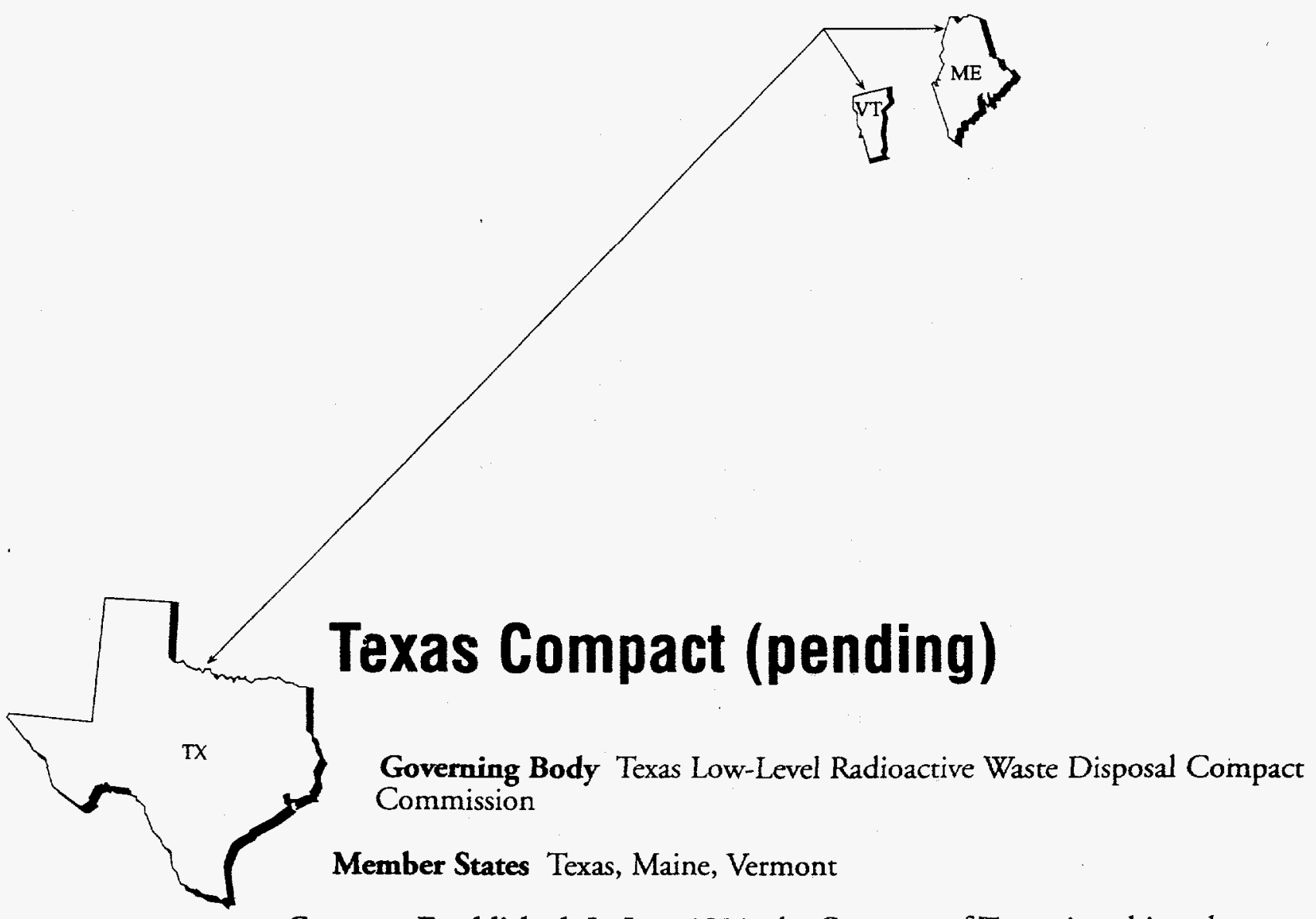

Compact Established In June 1993, the Governor of Texas signed into law legislation establishing a low-level radioactive waste compact with Maine and Vermont. Maine completed its approval process with the passage of a referendum on November 2, 1993. Vermont adopted the compact on April 25, 1994. The compact was submitted to the U.S. Congress for consent in the summer of 1994, but action was not taken. Congressional consent is expected in early 1996.

Current Waste Management As of July 1, 1995, waste may be shipped to the disposal facility in Barnwell, South Carolina. In addition, subject to the Northwest Compact rules of April 20, 1995, wastes meeting Envirocare of Utah's license conditions are being shipped for disposal at the Envirocare facility. Certain NARM wastes meeting the State of Washington's conditions are being shipped to the commercial disposal facility in Hanford, Washington. 


\title{
Host State: Texas
}

\author{
Regulatory Responsibility Texas Natural Resource Conservation Commission \\ Program Responsibility Texas Low-Level Radioactive Waste Disposal Authority (Authority) \\ Siting Responsibility Texas Low-Level Radioactive Waste Disposal Authority \\ Other Involvement Texas Department of Health
}

Disposal Technology below-ground concrete canisters

Siting The Authority began statewide site screening activities under newly enacted state law in 1983 . Initial efforts identified several desirable sites in south Texas. In 1985, the Texas Legislature instructed the Authority to give preference in its site search to state-owned land. In 1987, the Authority identified several possible sites in Hudspeth County, Texas, including a site at Fort Hancock. El Paso County and others filed a lawsuit to enjoin the Authority from selecting the Fort Hancock site, and the site was abandoned in early 1991. In May 1991, the Texas Legislature amended the Authority's statute, to require the selection of a site in a 400-square mile area near Sierra Blanca in Hudspeth County. In February 1992, the Authority selected a site on the Faskin Ranch for the state's proposed low-level waste disposal facility. The ranch was purchased and site characterization began. Site characterization concluded in November 1993.

Licensing The initial installment of the license application was submitted to the Texas Natural Resource Conservation Commission in March 1992. The application is now complete. Licensing review is under way and should be complete in March 1996.

Development Costs To date: $\$ 36$ million. Estimated total cost including construction: $\$ 90$ million.

Disposal Facility Operational Projected by mid-1997 contingent upon the outcome of administrative review and litigation. 


\section{Unaffiliated States}

\section{Massachusetts}

Primary Regulatory Responsibility

\section{Secondary Regulatory Responsibility}

\section{Program and Siting Responsibility}

Disposal Technology
Department of Public Health

Department of Environmental Protection

Low-Level Radioactive Waste Management Board (Management Board)

\section{Low-Level Radioactive Waste Management Board}

Shallow land burial is prohibited in Massachusetts; the chosen technology must allow monitoring and package retrieval. After a site is selected, the disposal technology will be chosen by the sited community from methods certified by the Management Board.

Current Waste Management As of July 1, 1995, waste may be shipped to the disposal facility in Barnwell, South Carolina. In addition, subject to the Northwest Compact rules of April 20, 1995, wastes meeting Envirocare of Utah's license conditions are being shipped for disposal at the Envirocare facility. Certain NARM wastes meeting the State of Washington's conditions are being shipped to the commercial disposal facility in Hanford, Washington.

Siting The Management Board continues to work on its two-track effort to discuss out-of-state disposal solutions with other states and compacts while also pursuing an in-state disposal facility siting process. In addition to using the three-stage technical site screening process required by state law, the Management Board developed draft policies and regulations for a program to encourage volunteered sites. Issued for public review and comment in April 1995 were a Draft Volunteer Sites Program Plan, draft regulations to implement the plan and to provide for local technical assistance and planning funds, and a Draft Siting Plan. Public comments were received through July 1995 following six public hearings and briefing sessions held during May and June. The Management Board is evaluating these comments and will finalize the documents in early 1996.

In April 1995, the Management Board contracted with Foster Wheeler Environmental Corp. for technical services to support its first stage of technical screening, called Statewide Mapping and Screening. (The other two stages will follow the initial implementation of the Volunteer Sites Program.) A Draft Statewide Mapping and Screening Protocol and Procedures will be issued in January 1996 for public review and comment through March, before the actual screening activities begin using the state's Geographic Information System-MassGIS.

Foster Wheeler completed a second contract in December 1995 assisting the Management Board in identifying "preference" siting criteria and in preliminarily evaluating options for their application. The Management Board will initiate a series of meetings during 1996 and early 1997 to finalize the preference criteria policies.

Licensing The projected date for submittal of a license application is 2000 .

Development Costs To date: not provided. Estimated total costs of preoperation and initial construction for a hypothetical above-ground vault facility without a cover have been developed based on four potential facility capacities: 35,000 cubic feet per year $-\$ 47.5$ million; 50,000 cubic feet per year- $\$ 48.7$ million; 80,000 cubic feet per year - $\$ 49.8$ million; 467,000 cubic feet per year - $\$ 65.7$ million.

Disposal Facility Operational Projected by 2001/2002. 


\section{Unaffiliated States (continued)}

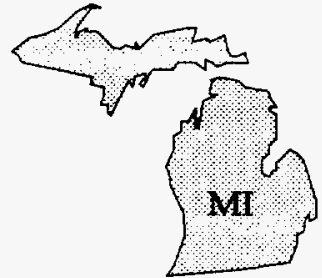

Disposal Technology

\section{Michigan}

\section{Regulatory Responsibility Michigan Department of Public Health Michigan Department of Natural Resources U.S. Nuclear Regulatory Commission (Michigan is not an Agreement State.) \\ Program and Siting Responsibility}

State law limits disposal technology to above- or below-ground vaults or aboveor below-ground modular canisters. No final determination has been made on facility design.

Current Waste Management As of July 1, 1995, waste may be shipped to the disposal facility in Barnwell, South Carolina. In addition, subject to the Northwest Compact rules of April 20, 1995, wastes meeting Envirocare of Utah's license conditions may be shipped for disposal at the Envirocare facility. Certain NARM wastes meeting the State of Washington's conditions may be shipped to the commercial disposal facility in Hanford, Washington.

Siting As required by amendments to state law, a policy advisory board issued a series of recommendations in September 1995. The board's report included specific recommendations regarding the conduct of a volunteer host community process, revisions to state siting criteria, and consideration of compact options. The Authority is now pursuing amendments to state law that would conform state law to the recommended volunteer process.

Licensing A projected date for submittal of a license application is not available.

Development Costs To date: $\$ 12$ million. Estimated total cost including construction: not available.

Disposal Facility Operational A projected date is not available. 


\section{Unaffiliated States (continued)}

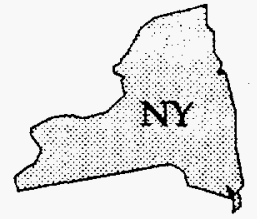

Siting Responsibility

Other Involvement

\section{New York}

\section{Regulatory Responsibility Department of Environmental Conservation}

(DEC)

\section{Program Responsibility New York State Energy Research and} Development Authority (NYSERDA)

in transition (see siting below)

Department of Health (DOH)

New York City Department of Health

Department of Labor (DOL)

New York State Citizens Advisory Committee on Permanent Disposal Facility Siting and Disposal Method Selection

Current Waste Management As of July 1, 1995, waste may be shipped to the disposal facility in Barnwell, South Carolina. In addition, subject to the Northwest Compact rules of April 20, 1995, wastes meeting Envirocare of Utah's license conditions are being shipped for disposal at the Envirocare facility. Certain NARivi wastes meeting the State of Washington's conditions are being shipped to the commercial disposal facility in Hanford, Washington.

\section{Disposal Technology}

State law bars shallow land burial; above-grade vaults identified as tentative preferred technology.

Siting New York's siting program is in transition. The State Budget for FY 1995-96 phased out the activities of the Low-Level Radioactive Waste Siting Commission, which was established in 1987 to select a site and disposal method. The state, under Governor George Pataki, is reevaluating its approach to low-level radioactive waste management. Several relevant proposals have been put before the state legislature, including one that would provide for a volunteer siting process. No new schedule has been developed. Regulations governing site and disposal method selection were adopted by DEC in 1987.

Licensing NYSERDA is responsible for obtaining a DEC permit to construct and operate a land disposal facility and a DOL radioactive materials license, once a site and a disposal method are selected.

Development Costs Through September 30, 1995, \$65.9 million has been collected through annual assessments on operating nuclear power plants (does not include surcharge rebates); $\$ 55.2$ million has been spent on siting, regulation development, public participation and related activities. Estimated total cost including construction: not available at this time.

Disposal Facility Operational The DEC issued financial assurance regulations in September 1991 and regulations for design, construction, operation, closure, post-closure and institutional control in March 1993. NYSERDA is responsible for construction and operation. 


\section{Unaffiliated States (continued)}

\section{South Carolina}

Regulatory Responsibility Division of Radioactive Waste Management, Bureau of Solid and Hazardous Waste, South Carolina Department of Health and Environmental Control

Program Responsibility

Other Involvement

Current Waste Management Waste is disposed of at the disposal facility in Barnwell, South Carolina. In addition, subject to the Northwest Compact rules of April 20,1995, limited mixed wastes meeting Envirocare of Utah's license conditions are being shipped for disposal at the Envirocare facility. Certain NARM (radium) wastes meeting the State of Washington's conditions are being shipped to the commercial disposal facility in Hanford, Washington.

Radioactive Waste Management, Bureau of Solid and Hazardous Waste, South Carolina Department of Health and Environmental Control-for Barnwell site

Chem-Nuclear Systems, Inc.-facility operation

\section{Disposal Technology enhanced shallow land disposal}

Licensing A license authorizing possession and storage of waste at the Barnwell facility was first issued on November 6, 1969. On April 13, 1971, the license was amended to authorize disposal. The license has been renewed for a five-year period ending July 31, 2000.

Disposal Facility Operational The Barnwell facility has been in operation since 1969. (See above.)

Other Information The Appropriations Act for FY 1995-96, which became effective June 29, 1995, required the Governor to appoint a Low-Level Radioactive Waste Compact Negotiating Committee. The committee is directed to negotiate with representatives of other states to establish a new low-level radioactive waste management compact, subject to conditions set forth in the statute. New regulations affecting the Barnwell disposal technology became effective January 1, 1996. 


\title{
Unaffiliated States (continued) $\cdots$
}

$\diamond \mathrm{DC}$

\section{District of Columbia}

\author{
Regulatory Responsibility Department of Consumer and Regulatory Affairs (DCRA) \\ Program Responsibility Department of Consumer and Regulatory Affairs \\ Service Facility Regulation Administration
}

Current Waste Management As of July 1, 1995, waste may be shipped to the disposal facility in Barnwell, South Carolina. In addition, subject to the Northwest Compact rules of April 20, 1995, wastes meeting Envirocare of Utah's license conditions may be shipped for disposal at the Envirocare facility.

Siting Because of the dense population and geographic size of the District of Columbia, and because of the relatively low volume of low-level radioactive waste generated within the district, DCRA is not planning to site a facility.

Other Information The District of Columbia is continuing efforts either to join a compact or to contract with one.

$\mathrm{NH}$

New Hampshire

Current Waste As of July 1, 1995, waste may be shipped to the disposal facility in Barnwell, Management South Carolina. In addition, subject to the Northwest Compact rules of April 20, 1995, wastes meeting Envirocare of Utah's license conditions are being shipped for disposal at the Envirocare facility.

Siting New Hampshire has no plans to site a disposal facility due to the small amounts of low-level radioactive waste generated.

Other Information The Governor's Ad Hoc Committee, with the assistance of the State Radiation Advisory Committee, continues to welcome an opportunity to discuss contracts or compacts with any interested state.

PR

\section{Puerto Rico}

Puerto Rico is not planning to site a disposal facility. Further information is unavailable at this time. 


\section{Unaffiliated States (continued)}

RIS Rhode Island

Regulatory Responsibility Rhode Island Department of Health

Program Responsibility Rhode Island Department of Health

Siting Responsibility none

Other Involvement Rhode Island Radiation Advisory Commission

Current Waste Management As of July 1, 1995, waste may be shipped to the disposal facility in Barnwell, South Carolina. In addition, subject to the Northwest Compact rules of April 20, 1995, wastes meeting Envirocare of Utah's license conditions are being shipped for disposal at the Envirocare facility. Certain NARM wastes meeting the State of Washington's conditions are being shipped to the commercial disposal facility in Hanford, Washington.

Siting The state is not planning at this time to site a facility.

Other Information The Rhode Island Radiation Advisory Commission has met with a representative of the Massachusetts Low-Level Radioactive Waste Management Board to get a brief update on the board's plans. 


\section{Commercial Low-Level Radioactive Waste Disposal Capacity Development Chart}

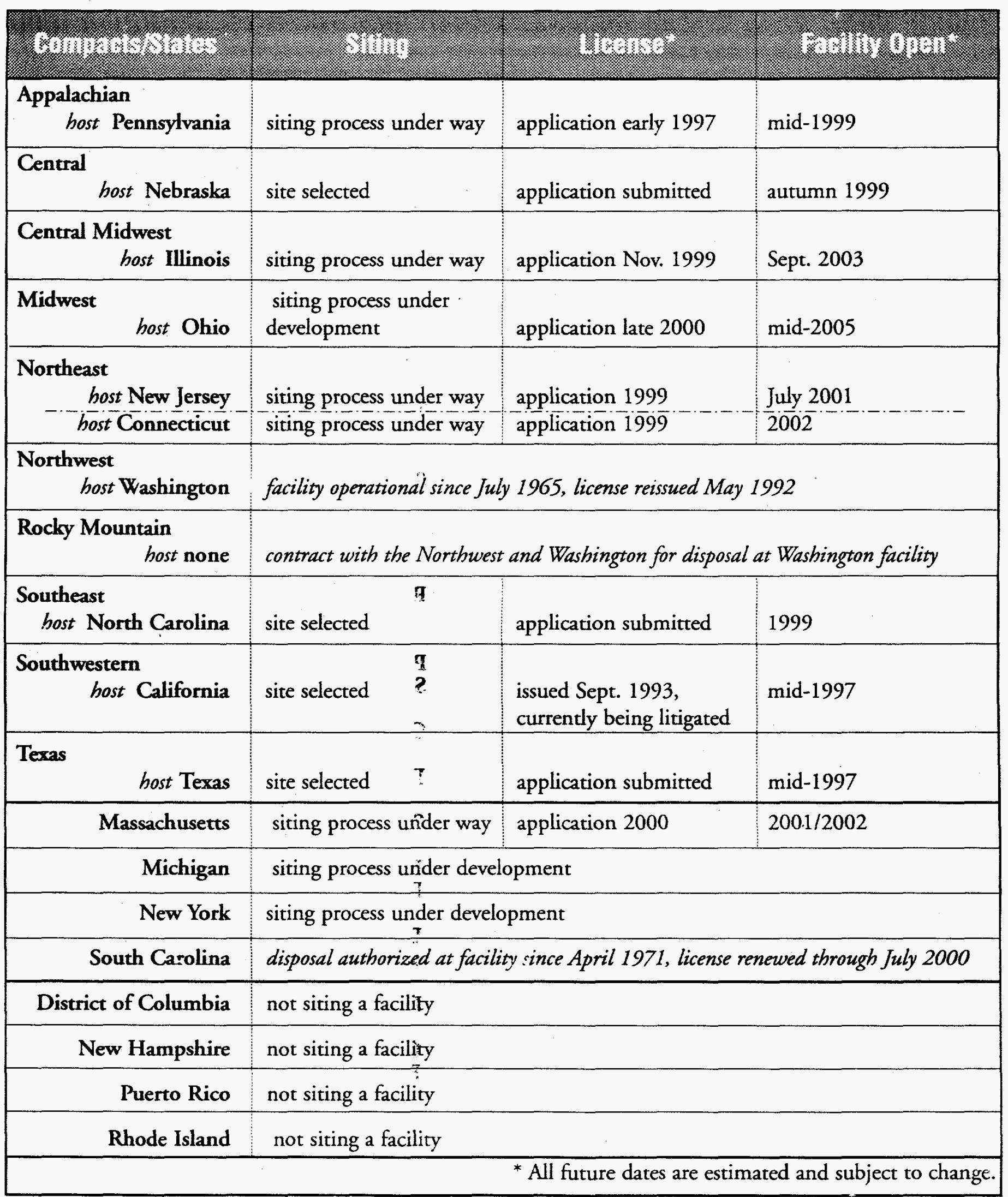

Graphic by Afton Associates for the LLW Forum. January 1996.

LLW Forum cfo Afton Associates, Inc. 403 East Capitol Street? Washington, D.C. 20003 - (202)547-2620 • FAX (2ن2)547-1668 • INTERNET Ilwforum@aol.com 


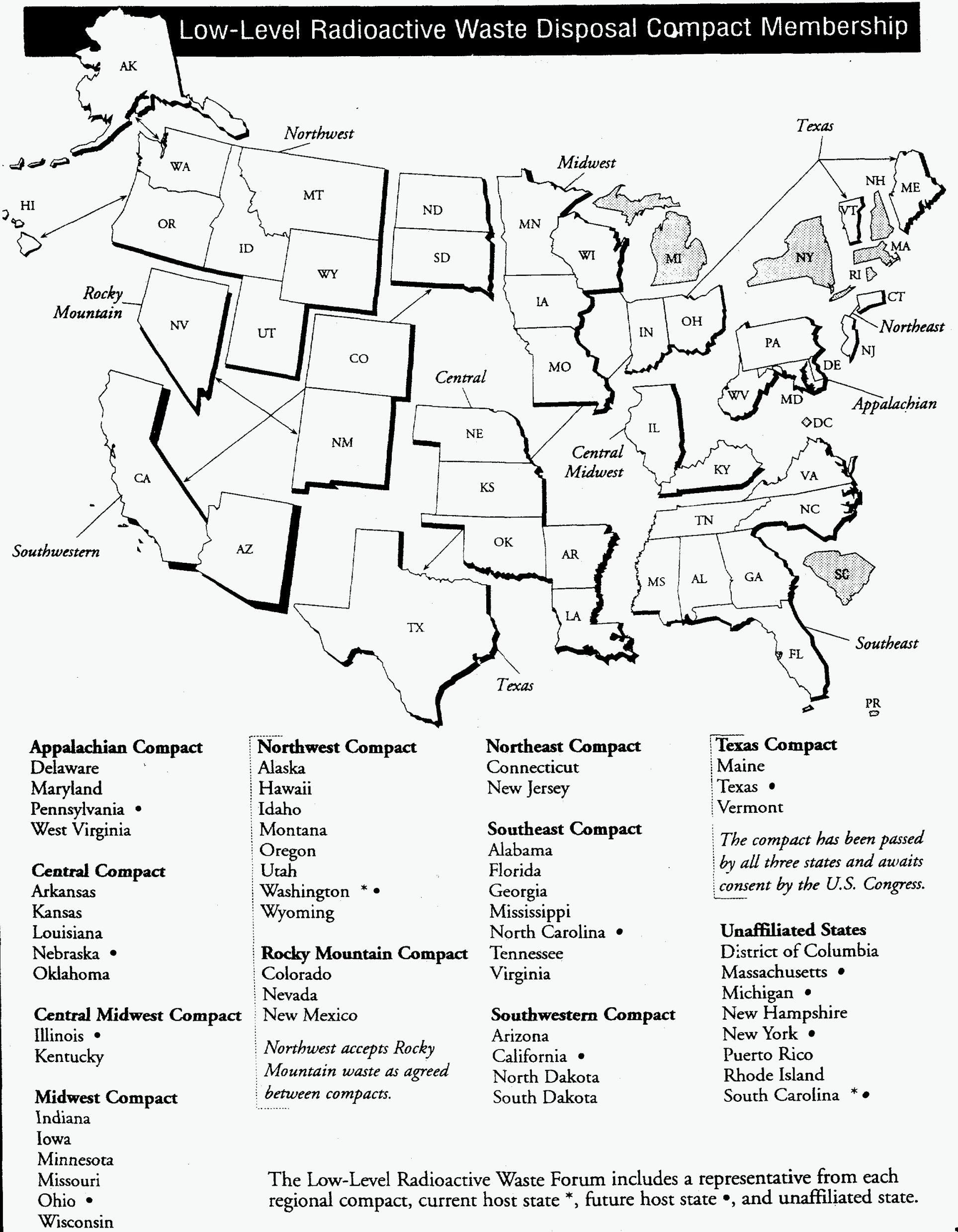

